\title{
Systemic lupus erythematosus and infections
}

\author{
B.K. Singh ${ }^{1}$, S. Singh ${ }^{2}$ \\ ${ }^{1}$ Rheumatology \& Immunology, Santokba Durlabhij Memorial Hospital, Jaipur: \\ ${ }^{2}$ Pathology, RUHS, Jaipur, India
}

\begin{abstract}
SUMMARY
Systemic lupus erythematosus (SLE) is an inflammatory and multi-systemic autoimmune disorder, characterized by an uncontrolled auto-reactivity of B and T lymphocytes, leading to the production of autoantibodies against self-directed antigens and tissue damage. The life expectancy in patients with SLE has improved tremendously in the last two decades, but the mortality rates still remain three times greater compared to those of the general population. Despite increased awareness and improved management, infections remain a major source of morbidity, mortality, hospitalization, and death in patients with SLE. The infections in SLE patients widely range from opportunistic to common bacterial and viral infections with typical or atypical presentations. Moreover, SLE patients exhibit an increased susceptibility to hospital-acquired infections. Factors associated with increased risk of infections include high disease activity, specific immune dysregulation, drug-induced immune deficiency, and organ failure with irreversible damage. Furthermore, immunosuppressive agents may make patients more susceptible to opportunistic infections. A big challenge faced by physicians in these patients is to distinguish between infections and flares of SLE, as infections may mimic them, leading to predicament in diagnosis and appropriate management. Immunosuppression used to treat severe flares of lupus can have catastrophic complications in patients with active infections. There is an urgent need for biomarkers to make an accurate differential diagnosis in this situation. In spite of increased understanding of SLE, many questions remain unanswered. Further research is needed to determine specific immune dysregulation underlying the increased susceptibility to specific infections, predictors of infection in SLE such as genetic markers, and biomarkers that discriminate between disease activity and active infections. Also, measures must be evaluated appropriately to prevent infections, and their complications in SLE.
\end{abstract}

Key words: Systemic lupus erythematosus; infections.

Reumatismo, 2020; 72 (3): 154-169

\section{INTRODUCTION}

ystemic lupus erythematosus (SLE) $\checkmark$ is an autoimmune inflammatory and multi-system disorder characterized by excessive auto-reactivity of B and T lymphocytes.

Infections are one of the most frequent causes of morbidity, hospitalization and death in patients with SLE. Immune dysregulation may play a role in the susceptibility of SLE patients to infections. Furthermore, immunosuppressive agents may increase the risk for infections.

Corresponding author:
In the EuroLupus cohort, $36 \%$ of patients had infections during follow-up, and approximately $30 \%$ of deaths were related to infections in the five-year-follow-up. (1) Infections have been well documented as cause for hospitalization and mortality in the Hopkins Lupus and British University College cohorts $(2,3)$. Infections remain a major source of morbidity and mortality among SLE patients (4). There is a bimodal curve of the mortality rate in these patients with an initial peak occurring at the early stage of the disease, related to disease activity, which is followed at a later stage by cardiovascular disease, damage accrual, and infections (5). The range of infections in lupus patients varies widely from bacterial and viral infections to opportunistic infections with normal or abnormal presentations. Moreover, SLE patients show a 
greater susceptibility to hospital-acquired infections.

Factors associated with an increased risk of infection include: high disease activity, immune dysregulation, drug-induced immune deficiency and organ failure due to irreversible damage. Infections may mimic SLE flares causing confusion in the diagnostic process and treatment selection. Fever, lymphadenopathy, confusion state, pulmonary infiltrates, skin and mucosal rashes/ ulcer, coagulopathy and renal impairment pose diagnostic challenges. Evidence suggests that certain infections, particularly of viral nature, might contribute to the onset of this disease, and to flares or worsening of an active lupus (6).

\section{EPIDEMIOLOGY OF INFECTIONS}

The type of microorganisms involved is influenced by various environmental factors, e.g.

1) the patterns of disease arising from reactivated latent infections;

2) opportunistic infections;

3) invading pathogens.

Infection rates, organism presentation, and severity of infections vary between the developing and developed countries. Infections due to tuberculosis, Staphylococcus aureus, Streptococcus pneumoniae, Pseudomonas aeruginosa, Escherichia coli and Candida, with frequent mixed viral and bacterial infections and poor prognosis, are more common in developing countries while the incidence of tuberculosis is much lower in developed countries (7). Infectious diseases are reported to be more common and twice as dangerous in developing countries; in them an increase in infection rates with Pneumocystis jirovecii has been observed (8). This difference can be explained by poverty, overpopulation, malnutrition, poor water and food sanitation, decreased awareness and poor healthcare service infrastructures and availability in developing countries (7). In a nested case control study in 93 SLE patients, Gladman et al. (9) reported pneumonia (29.7\%), skin $(23.6 \%)$, genitourinary $(18.2 \%)$ and gas- trointestinal tract infections in $6 \%$ of patients. S. aureus, E. coli and P. aeruginosa were the most common pathogens (10-13). More suspicion of opportunistic pathogens, together with earlier evaluation and appropriate therapy, are required to decrease the infectious disease burden and its complications in patients with SLE.

\section{Bacterial infection}

About $80 \%$ of SLE infections are caused by bacteria. The most frequent sites of infection are respiratory tract, skin, and urinary tract, accounting for more than $60 \%$ of the infections seen in SLE patients. Most infections are caused by $S$. aureus, $S$. pneumoniae, E. coli, and $P$. aeruginosa. Infection due to Salmonella species is more common in SLE patients than in the normal population, and is attributed to splenic dysfunction. Neutropenia caused by antigranulocyte antibodies through direct cytotoxicity and opsonization was found in approximately $50 \%$ of patients with SLE and predisposed them to bacterial infection in the Hopkins Lupus Cohort. In this cohort a significant difference in the SLEDAI scores was demonstrated between patients who developed bacteremia and those who did not. These authors concluded that SLE activity (SLEDAI) was a predictive factor for hospitalization due to infection (3).

\section{Viral infections}

Viruses such as cytomegalovirus (CMV), Epstein-Barr virus (EBV), and parvovirus B19, are environmental agents that may trigger the development of SLE. Moreover, SLE patients are at an increased risk for viral diseases.

Herpes zoster (HZ) is the most frequent infection in lupus patients with an annual incidence ranging from 6.4 to $32.5 / 1000$ person-years, followed by other frequent infections like CMV, human papilloma virus (HPV), parvovirus B19, Hepatitis B, $\mathrm{C}$ and influenza $(9,14)$. HZ is the symptomatic reactivation of the Varicella-zoster virus (VZV), since the virus remains dormant in the dorsal root ganglia for long periods of time after primary infection. This latent virus is controlled predominantly 
by cellular immune mechanisms and may be reactivated due to immune imbalance. The incidence rate of $\mathrm{HZ}$ reactivation is 2-3-fold greater in SLE patients than in the general population (15). Ten to $20 \%$ of lupus patients have more severe forms of infection, ocular involvement, post-herpetic neuralgia and disseminated disease (16). Higher incidence of CMV infections has also been reported in patients with SLE, often presenting with severe and atypical manifestations. CMV infection may mimic a lupus flare and cause pneumonia, arthritis, lymphadenopathy, gastro-intestinal bleeding or encephalitis, which is found to be more severe with immune-suppressants like cyclophosphamide $(17,18)$.

The majority of SLE patient are infected with EBV. A poor control of EBV infection could result in widespread latent infection and more frequent reactivation (17). The correlation of HCMV infection in the pathogenesis of SLE has not yet been established. Some studies have shown that the frequency of HCMV-specific CD69+, CD4+, T cells producing IFN- $\gamma$ and TNF- $\alpha$ was similar in SLE patients and in healthy. Cassaniti et al. observed a significantly lower EBV and HCMV-specific T cell response in SLE patients, thus explaining the possible burden of these infections. Women with SLE have both a high prevalence of HPV infections and also an increased risk of squamous intraepithelial lesions (SIL). They show a three-fold increase in the rate of abnormal cervical cytology smears compared to the general population (19). The annual incidence of viral infections in SLE patients has not been studied much so far. The influenza vaccine has been shown to be associated with an increase in autoantibody formation in some patients. However, this does not correlate with clinical flares of lupus (20). Given the risk of potentially more severe influenza exposure in patients with SLE, annual vaccination is recommended (21).

In the HIV infected population the incidence of SLE is reported to be lower than in the general population. Some research suggested that the evolution of SLE can be suppressed by the immunosuppression re- sulting from HIV infection. Conversely, a reactivation of SLE was observed in some HIV patients (22). The incidence of hepatitis B and C infection in SLE is reported to be same as in the general population. However, patients treated with MABs TNF inhibitors and rituximab may be at an increased risk of hepatitis reactivation.

\section{Mycobacterial infection}

In endemic countries, the incidence of Mycobacterium tuberculosis (TB) active infection in patients with SLE is approximately $5-7 \%$, while $18-25 \%$ of them has latent tuberculosis (23). TB in SLE occurs commonly in extra pulmonary sites (CNS, joints, skin, and lymphnodes) and may be associated with more severe pulmonary and disseminated involvement $(24,25)$. The most important risk factors for TB reactivation is the use of biologics, like TNF inhibitors, and glucocorticoids. SLE patients have an increased incidence of both tuberculous mycobacterium (MTB) and nontuberculous mycobacterium (NTM) infections.

Pathogenic NTM affects skin, lungs, lymphnodes, soft tissues, and bones, and rarely disseminate. NTM presentation may be subtle with multiple sites of involvement, is more commonly found in patients with longer lupus disease duration, in older patients, patients with concomitant diabetes and higher cumulative doses of prednisolone. The possible route of transmission is the penetration of the pathogen through a skin abrasion. M.chelonae, M.avium complicated (MAC) and M.haemophilum cause cutaneous infections in SLE (26). Synovitis is mainly monoarticular and also the periarticular tissue may be involved. M.fortuitum, MAC, and M.marinum are common NTM causing synovitis. A tissue culture is often required for a definitive diagnosis (27).

\section{Fungal infection}

Invasive fungal infection (IFI) is a lifethreatening condition occurring occasionally in SLE patients. IFI is mainly caused by opportunistic pathomycetes, including Candida, Aspergillus and Cryptococcus, which may affect lungs, spleen, CNS, 
pharynx, esophagus, urinary tract, or may present as fungemia. The use of glucocorticoids or other immunosuppressants, several antibiotics and steroid-induced diabetes contribute to the immune dysfunction which increases the susceptibility to IFI. Fan et al. (28) studied 1534 SLE patients of whom 20 patients had IFI. The affected sites included the lungs in nine patients and the central nervous system in five. Five cases of disseminated IFI were also reported. Aspergillus (33.3\%) and Cryptococcus neoformans $(33.3 \%)$ were the most common species, followed by Candida albicans $(22.2 \%)$, thus confirming the results of previous studies. Six (30\%) patients expired: two from lung IFI, two from central nervous system IFI and two from disseminated IFI. These patients were taking significantly higher prednisone doses and had significantly higher serum $C$ reactive protein (CRP), erythrocyte sedimentation rate (ESR), thrombocytopenia and systemic lupus erythematosus disease activity index (SLEDAI) scores (29-32).

\section{Pneumocystis jiroveci}

This pathogen is recognized as a frequent cause of severe pulmonary involvement in immunosuppressed patients. SLE patients have shown higher severity and mortality rates. Higher disease activity, higher dose of prednisolone, renal involvement, lower absolute lymphocyte count and lower CD4+ count are risk factors for $P$. jiroveci pneumonia infection.

\section{Parasites}

Toxoplasmosis may complicate the clinical picture of SLE patients, presenting as cerebritis and pericarditis, mimicking disease flares and causing significant morbidity and mortality. Interestingly, Toxoplasma infection can also occur in patients with low disease activity and low steroid dosage $(33,34)$.

\section{Infections that mimick SLE}

It is sometime difficult to distinguish between viral infection and SLE manifestations. Human parvovirus B19 (HPV-B19) infection and Lehismania are common infections with SLE-like characteristics. The similarities between these infections and SLE include arthralgia, photosensitivity, fever, fatigue, lymphadenopathy and serological abnormalities. In these cases it is important to identify diligently any potential contact with individuals affected by erythema infectiosum.

\section{MORBIDITY AND MORTALITY DUE TO INFECTIONS}

\section{Diagnostic and clinical considerations}

Fever in SLE patients presents often a dilemma in the differential diagnosis between a flare of the disease and a superimposed infection. Therefore, it is necessary to understand if there is an infection in progress and if and when to start empirical antibiotics, and to decide whether to change the immunosuppressive treatment.

Fever associated with SLE presents more frequently with serositis, kidney damage, cytopenia, lymphadenopathies, or thrombosis. Kidney involvement and anti-Ro positivity are associated with SLE fever, although with low odd ratios. Conversely, discoid lesions are not associated with SLE fever. This could help in the differential diagnosis. Considering the effect of treatment is of importance in SLE patients with infection. Because of the impaired inflammatory response, signs and symptoms of infection may be subtle, especially in patients receiving cytotoxic drugs. Furthermore, SLE is associated with false positive serological tests, such as those for syphilis, HIV, Lyme disease, toxoplasmosis, and several other common infections, explained by the underlying polyclonal hyperglobulinemia.

Additionally, glucocorticoid treatment may result in false negative skin tests e.g. tuberculin skin testing. $\mathrm{C}$ reactive protein (CRP) is an acute phase reactant that is found to be elevated in infections and many autoimmune states. However, CRP levels are normal in SLE patients and do not reflect disease activity. It was suggested that increased CRP can be considered as a surrogate marker of infection in SLE to distinguish between disease activity and infec- 
tion. However, available studies reported conflicting results (35-40).

In SLE patients receiving prednisone at maintenance doses or greater, SLE fever is rare. When fever does develop, it is usually due to infection. A mean dosage of prednisone of $28 \mathrm{mg} /$ day (range 20 to 40 $\mathrm{mg} /$ day) completely suppresses SLE fever within $24 \mathrm{~h}$. Lower serum C3 and higher SLEDAI scores are associated with SLE fever. Immunotherapy especially with azathioprine is a risk factor for infection fever. Furthermore, SLE reactivation and infection may co-occur (8\%).

Low soluble Fcgamma receptor III levels and elevated G-CSF levels are proposed as novel indicators infection (41) in SLE patients with sepsis. In another study, elevated levels of sE-Selectin and sICAM-1 were reported by Egerer et al. (42). They observed elevated concentrations of sCD14 in sera from SLE patients, which rapidly decreased after effective antibiotic therapy. A continuous elevation of these three parameters was associated with a fatal outcome in both sepsis and SLE patients (42). Recently evidence suggests that serum procalcitonin has negative predictive value for bacterial infection in active SLE.

Anti-CRP antibody is found in one third of lupus patients to be associated with anti DsDNA antibodies and Lupus nephritis. However, the presence of the anti-CRP antibody was not associated with disease activity in SLE.

\section{Vaccination}

Vaccination is an attractive method to prevent certain infections. It was suggested that efficacy of vaccinations may be reduced in patients with SLE. However, the majority of these patients develop protective levels of antibodies after vaccination. There is also a concern of disease flares after vaccinations, which, however, was not found to be significant (43-52). It is recommended to avoid live attenuated vaccines and vaccines to be given in stable disease, preferably 2-4 weeks before initiating the immunosuppressant/biological therapy. Vaccination is a safe procedure for secondary prophylaxis. Pneumococcal and influenza vaccinations are routinely recommended (53).

\section{Susceptibility to infections in SLE patients}

The susceptibility to infections in SLE patients might also be defined based on various intrinsic and acquired defects in the immune system associated with this disease or with immunosuppressive therapies. A summary of infective agents involved in SLE (Table I), of the relevant studies examined in this review (Table II), of infectionrelated mortality (Table III), and of the risk factors for infection (Table IV) is reported (9-13, 35, 36, 45-60).

Table I - Pathogenic organisms responsible for infections in SLE.

\begin{tabular}{|l|l|}
\hline Bacteria & Staphylococcus aureus \\
& Pseudomonas spp \\
& Escherichia coli \\
& Streptococcus pneumonia \\
& Neisseria spp \\
& Salmonella species \\
& Non-typhoidal salmonella \\
& Haemophilus influenza \\
& Klebsiella spp \\
& Acinetobacter spp \\
& Listeria monocytogens \\
& Mycoplasma spp \\
\hline Mycobacterium & M. tuberculosis \\
& Nontuberculous mycobacterium \\
& Mycobacterium chelonae \\
& M. avium complex (MAC) \\
& M. Haemophilum \\
& M. Fortuitum \\
& M. Marinum \\
\hline Virus & Parvovirus B19 \\
& Cytomegalovirus \\
& Epstein-Barr virus \\
& Herpes simplex/varicella zoster \\
& Human papillomavirus \\
& Hepatitis A \\
& Hepatitis B \\
& Hepatitis C \\
\hline Fungus & Candida spp \\
& Aspergillus spp \\
& Cryptococcus Neoformans \\
& Pneumocystis jiroveci \\
& Histoplasma Capsulatum \\
& Nocardia spp \\
& Coccidoides immitis \\
& Toxoplasma Gondi \\
& Strongyloides Stercoralis \\
\hline
\end{tabular}


Table II - Studies on infections in SLE.

\begin{tabular}{|c|c|c|c|}
\hline Author/Year & $\begin{array}{l}\text { Number } \\
\text { of patients } \\
\text { observed }\end{array}$ & $\begin{array}{l}\text { Number } \\
\text { of patients had } \\
\text { infections }\end{array}$ & Main Site/Pathogens \\
\hline $\begin{array}{l}\text { Costa-Reis et al., } \\
2013 \text { (13) }\end{array}$ & 120 & 44 & $\begin{array}{c}\text { S. aureus - } 5(11.4 \%) \\
\text { E. coli - } 6(13.6 \%) \\
\text { Pseudomonas - } 2(4.5 \%) \\
\text { Herpes simplex - } 4(9 \%) \\
\text { Herpes zoster - } 8(18.1 \%) \\
\text { S. pneumoniae - } 2(4.5 \%)\end{array}$ \\
\hline $\begin{array}{l}\text { Navarro-Zarza et al., } \\
2010 \text { (35) }\end{array}$ & 473 & $\begin{array}{c}268 \\
\text { (Confirmed 96) }\end{array}$ & $\begin{array}{l}\text { Mycobacterium tuberculosis } 6(4.5 \%) \\
\text { Staphylococcus sp. } 21(15.0 \%) \\
\text { Streptococcus sp. } 16(12.1 \%) \\
\text { Escherichia coli } 64(48.4 \%) \\
\text { Candida sp } 8(23 \%)\end{array}$ \\
\hline $\begin{array}{l}\text { Ruiz-Irastorza et al., } \\
2009 \text { (36) }\end{array}$ & 249 & 83 & $\begin{array}{l}\text { E. coli - } 7(16 \%) \\
\text { S. aureus - } 6(14 \%) \\
\text { M. tuberculosis - } 6(14 \%) \\
\text { S. pneumoniae - } 5(12 \%) \\
\text { Salmonella - } 4(9 \%) \\
\text { Candida sp. } 3(7 \%)\end{array}$ \\
\hline $\begin{array}{l}\text { Al-Rayes et al., } \\
2007 \text { (10) }\end{array}$ & 199 & 117 & $\begin{array}{c}\text { Staphylococcus aureus - } 37(18.59 \%) \\
\text { Escherichia coli - } 21 \text { (10.55\%) } \\
\text { Pseudomonas aeruginosa - } 17(8.54 \%) \\
\text { Salmonella - } 12 \text { (6.03\%) } \\
\text { Mycobacterium tuberculosis - } 11(5.52 \%) \\
\text { Streptococcus sp. - } 11(5.52 \%) \\
\text { Candida albicans - } 37(18.59 \%)\end{array}$ \\
\hline $\begin{array}{l}\text { Bosch et al., } \\
2006 \text { (12) }\end{array}$ & 110 & 39 & $\begin{array}{c}\text { E. coli - } 10(21.3 \%) \\
\text { S. aureus - } 7(14.9 \%) \\
\text { Candida sp. - } 6(12.7 \%) \\
\text { H. zoster - } 5(10.6 \%) \\
\text { Salmonella sp. - } 4(8.5 \%) \\
\text { S. pneumonia - } 3(6.4 \%)\end{array}$ \\
\hline $\begin{array}{l}\text { Khalifa et al., } \\
2007 \text { (11) }\end{array}$ & 75 & 43 & $\begin{array}{c}\text { Staphylococcus aureus - } 16(19.5 \%) \\
\text { Escherichia coli - } 13(15.8 \%) \\
\text { C. albicans - } 11(13.4 \%) \\
\text { Streptococcus - } 9(10.9 \%) \\
\text { Proteus mirabilis - } 4(4.8 \%) \\
\text { M. tuberculosis - } 4(4.8 \%) \\
\text { Herpes zoster - } 3(3.6 \%) \\
\text { Enterobacter - } 2(2.4 \%) \\
\text { Klebsiella - } 1(1.2 \%) \\
\text { Hepatitis C virus - } 1(1.2 \%)\end{array}$ \\
\hline $\begin{array}{l}\text { Gladman et al., } \\
2002(9)\end{array}$ & 363 & 93 & $\begin{array}{c}\text { Staphylococcus - } 21(14.2 \%) \\
\text { E. coli - } 17(11.5 \%) \\
\text { HPV - } 14(9.4 \%) \\
\text { Streptococcus - } 12(8.1 \%) \\
\text { Herpes simplex - } 5(3.4 \%) \\
\text { Candida albicans - } 5(3.4 \%) \\
\text { Herpes Zoster - } 2(1.3 \%) \\
\text { Pseudomonas - } 1(0.7 \%) \\
\text { Atypical mycobacterium - } 1(0.7 \%)\end{array}$ \\
\hline
\end{tabular}


Table III - Infection-related mortality in SLE.

\begin{tabular}{|c|c|c|c|c|}
\hline Authors/Year & $\begin{array}{c}\text { Number } \\
\text { of patients }\end{array}$ & Site of Infections & Pathogens & $\begin{array}{l}\text { Deaths due } \\
\text { to infection }\end{array}$ \\
\hline $\begin{array}{l}\text { Fei et al., } \\
2014(45)\end{array}$ & 3,831 & $\begin{array}{l}\text { Meningitis - } 41.5 \% \\
\text { Pulmonary - } 24.6 \% \\
\text { Peritonitis - } 20.7 \% \\
\text { Urinary Tract - } 10.4 \% \\
\end{array}$ & $\begin{array}{c}\text { Fungal - } 10(62.5 \%), \\
\text { Bacterial - } 4(25.0 \%), \\
\text { Tuberculosis - } 2(12.5 \%)\end{array}$ & $101 / 268(37.3 \%)$ \\
\hline $\begin{array}{l}\text { Voss et al., } \\
2013 \text { (46) }\end{array}$ & 215 & $\begin{array}{c}\text { Sepsis - } 66 \% \\
\text { Gastrointestinal - 33\% }\end{array}$ & & $3 / 38(8 \%)$ \\
\hline $\begin{array}{l}\text { Zhen et al., } \\
2013 \text { (47) }\end{array}$ & 1,958 & $\begin{array}{c}\text { Pulmonary - } 64.7 \% \\
\text { Extrapulmonary - } 35.3 \%\end{array}$ & & $51 / 165(30.9 \%)$ \\
\hline $\begin{array}{l}\text { Sharma et al., } \\
2013 \text { (48) }\end{array}$ & 17 & $\begin{array}{c}\text { Sepsis - 40\% } \\
\text { Ventilator associated pneumonia - 20\% } \\
\text { CNS - 10\% } \\
\text { Skin\& Soft Tissue - 10\% } \\
\text { Pancreatitis - 10\% } \\
\text { Cysytitis - 10\% }\end{array}$ & $\begin{array}{c}\text { Aspergillus - } 30 \% \\
\text { Escherichia coli - 20\% } \\
\text { Candida - 20\% } \\
\text { Tuberculous Meningitis - 10\% } \\
\text { MRSA - } 10 \% \\
\text { Pseudomonas aeruginosa - 10\% }\end{array}$ & $10 / 17(58.8 \%)$ \\
\hline $\begin{array}{l}\text { Teh et al., } \\
2013(49)\end{array}$ & 251 & $\begin{array}{c}\text { Pneumonia - } 10.5 \% \\
\text { Sepsis - } 6.7 \% \\
\text { Cellulitis - } 6.7 \% \\
\text { Urinary tract infections - } 2.1 \% \\
\text { Meningitis - } 0.4 \% \\
\text { Septic arthritis - } 0.2 \% \\
\end{array}$ & $\begin{array}{c}\text { Gram-negative organisms } 66.7 \% \\
\text { Gram-positive organisms - } 6.1 \% \\
\text { Mycobacterium tuberculosis - } 1.5 \% \\
\text { Cryptococcal meningitis - } 0.7 \% \\
\text { Mycoplasma pneumoniae - } 0.7 \% \\
\text { Total } 130 \\
\end{array}$ & $17 / 26(65.3 \%)$ \\
\hline $\begin{array}{l}\text { Kang et al., } \\
2011 \text { (50) }\end{array}$ & 1010 & $\begin{array}{c}\text { Pneumonia }-65.2 \% 15 / 23 \\
\text { Sepsis - } 13 \% \\
\text { Abscess }-8.7 \% \\
\text { Peritonitis - } 4.3 \% \\
\text { Meningitis - } 4.3 \% \\
\end{array}$ & Bacterial & $52 \%$ Total 44 \\
\hline $\begin{array}{l}\text { Souza et al., } \\
2012 \text { (51) }\end{array}$ & 3133 & $\begin{array}{c}\text { Pneumonia }-25.7 \% \\
\text { Sepsis - } 22.8 \% \\
\text { Meningitis - } 0.3 \% \\
\text { Tuberculosis - } 0.6 \%\end{array}$ & Bacterial & $51.3 \%$ \\
\hline
\end{tabular}

Table IV - Risk factors for infection in patients with systemic lupus erythematosus.

\begin{tabular}{|l|l|}
\hline Disease related & Disease activity \\
& Nephritis \\
& CNS Lupus \\
& Lymphopenia/Leucopenia/ Neutropenia \\
& Irreversible organ damage/failure \\
\hline Genetics & Complement deficiency \\
& MBL polymorphism \\
& TLR polymorphism \\
& FCGR polymorphism \\
& TNFR polymorphism \\
& Osteopontin polymorphism \\
\hline Laboratory & High anti-dsDNA titers \\
& Low complements \\
& Anti-phospholipid antibodies \\
\hline Therapy related & Biologics (Anti CD 20 Ab, TNF Blockers) \\
& Cyclophosphamide high-dose regimens \\
& Methyl prednisolone high-dose pulses \\
& Prednisone-equivalent doses $>7.5-10 \mathrm{mg} /$ day \\
Immunosuppressants-Azathioprine, MMF, Methotrexate, Leflunamide etc.
\end{tabular}




\section{GENETIC SUSCEPTIBILITY}

\section{Defects in the complement system}

The complement system is composed of a complex cascade of plasma proteins that leads to deposition of $\mathrm{C} 3 \mathrm{~b}$ fragments and formation of immune complexes that leads to the activation of a lytic complex on the bacterial surface. Increased pyogenic infection rates are observed in patients with complement deficiencies. Congenital deficiency of early complement components associated with lupus may involve $\mathrm{C} 1 \mathrm{q}$, C1r, C2, C4 and C1-Inhibitor (61, 62). $\mathrm{C} 1 \mathrm{q}$ plays an important role in the classical pathway activation through the recognition of apoptotic material, antibodies and bacteria/viral proteins $(13,14)$. There is also a decreased expression of CR1 on neutrophils, causing defective phagocytosis (6366). The expression of CR1 and CR2 (C3d receptor) is also likely to be significantly low on B lymphocytes in lupus patients (67). Autoantibodies against the CR1 and CR3 (CD1lb/CD18) has also been recognized in lupus. In addition, the consumption of complement proteins by immune complexes (IC) also limits the amount of complement available for normal defense against pathogens $(68,69)$.

\section{Mannose-binding lectin}

Mannose-binding lectin (MBL) is a serum protein that is considered a recognition particle in the lectin pathway of complement activation. Besides, MLB may directly opsonize pathogenic microorganisms and activate phagocytes. Mok et al. reported an increase by $34.2 \%$ in the risk of bacterial infection for every decline in serum MBL level by one log, and by $22.8 \%$ for every increase in the number of major lupus exacerbations (70).

\section{Osteopontin (SPP1)}

It is a soluble ligand with pleomorphic immunologic activities, which is also involved in activation of macrophage chemotaxis, stimulation of Th1 responses and activation of B1 B-cells.

It has been associated with the development of murine lupus, and is overexpressed in humans with SLE. Forton et al. demon- strated that a silent polymorphism (707C $>\mathrm{T}$, rs1126616) of osteopontin was significantly associated with SLE. Additional associations with renal disease and opportunistic infections were also found (71).

\section{PTPN22 gene polymorphisms}

Protein tyrosine phosphatase non-receptor type 22 (PTPN22) gene was found to be related to SLE. The missense R620W polymorphism, rs 2476601, in PTPN22 gene at the nucleotide 1858 in codon 620 (620Arg $>$ Trp) proved to be significantly associated with SLE (72). The PTPN22 (1858T, G788A) locus was also found to be associated with an increased risk of pulmonary tuberculosis and chronic infections (73).

\section{Fcgamma receptor polymorphisms}

The G Immunoglobulin Fc Receptors $(\mathrm{Fc} \gamma \mathrm{R})$ belong to the TNFR5 receptors family of the immunoglobulin superfamily and are generally expressed in the immune system. They play an important role in the clearance of immune complexes. Several studies have shown an impaired handling of immune complexes in SLE due in part to the dysfunction of the $\mathrm{Fc} \gamma \mathrm{R}$. Among all types of $\mathrm{Fc}$ receptors, the Fc $\gamma$ RIIA, Fc $\gamma$ RIIB, Fc $\gamma$ RIIIA and Fc $\gamma$ RIIIB have well characterized polymorphisms that produce an alteration in the receptor function, which is associated with SLE, lupus nephritis and infection risk $(74,75)$.

\section{DEFECTS OF THE INNATE IMMUNE SYSTEM}

\section{Macrophage defects}

There are multiple defects of the macrophage/monocyte system that affect its antigen-presenting function and diminish the phagocytic activity of lupus monocytes (76). Decreased tumor necrosis factor (TNF) and superoxide generation by Fc'y receptor by mononuclear cells may also contribute to a deficient phagocytic ability and predisposition to bacterial infections (77). Circulating immunoglobulin IgM and IgG autoantibodies against this receptor (Fc'yRI, Fc'yRII, and Fc'yRIII) may interfere with its function (78). 


\section{Neutrophil defects}

Both the number and functions of PMN can be defective in lupus patients. Antibodies against the neutrophil cytoplasmic components, which correlate with neutropenia and can have an antibacterial activity (i.e. lactoferrin, elastase and lysozyme), were also found in SLE. However, their clinical importance has not yet been completely understood $(79,80)$. The deficiency of lactoferrin, a bacteriostatic protein, is associated with recurrent infections (81). Anti-neutrophil cytoplasmic antibodies (ANCA) activate neutrophils by occupying and cross-linking the Fc-/RIIa receptors (82). Neutrophil chemo taxis is also defective in SLE (83).

\section{Natural killer cell defects}

NK cells are an important part of innate immunity. Decreased numbers of NK cells have been reported in active SLE patients, in particular in the presence of infection. Anti-NK cells and antilymphocyte autoantibodies may contribute to decreased NK cell activity $(38,39)$.

\section{Spleen/reticuloendothelial system dysfunction}

CR1 on erythrocytes transport IC to the reticuloendothelial system (RES) organs. The spleen is the main organ of the RES. Spleen dysfunction has already been shown in SLE patients. The defective clearance of IgGsensitized erythrocytes from the blood circulation by the RES is associated with disease activity (84-89). High incidence of bacterial sepsis has been frequently reported in SLE patients with functional asplenia (90).

\section{DEFECTS OF ADAPTIVE IMMUNE SYSTEM}

\section{$T$ cell defects}

T-cell lymphopenia and especially CD4 + lymphopenia are the most commonly observed hematological abnormalities in lupus (79). Lymphopenia may contribute to increased susceptibility to infections and also correlates with disease flares. An inadequate production of cytokines (e.g. IL$2, \mathrm{IFN}-\gamma)$ is responsible for the defective cytotoxic $\mathrm{T}$ cells (84). There is also a reduced delayed hypersensitivity response in patients with SLE. Many patients with SLE have altered in-vitro immune responses to alloantigens and memory response and such dysfunction correlates with higher disease activity (77).

\section{$B$ cell and immunoglobulin defects}

Abnormalities include defects in the negative selection of auto reactive B cells at certain stages, pre-naive, transitional, pre-naive memory B cells and in particular plasma blast/plasma cells (85), although immunization produces reasonable immune response (86). Transient or permanent hypoglobulinemia with low $\mathrm{IgG}$ levels has also been described in SLE patients, who, in some cases, experienced repeated infections (35). An imbalance in the IgG sub-classes with a change in the $\operatorname{IgGl}: \operatorname{IgG} 2$ ratio and low $\mathrm{IgG} 2$ is reported in few patients; it is mainly aimed against polysaccharide antigens and encapsulated bacteria $(36,37)$.

\section{CONCOMITANT IMMUNODEFICIENCIES IN SLE}

\section{Common variable immunodeficiency}

The development of common variable immunodeficiency (CVID) or hypogammaglobulinemia in SLE is rare.

SLE evolves into a low activity state after development of CVID in most cases. CVID should be suspected in any patient who has SLE with recurrent sinopulmonary infections in the absence of SLE activity or immunosuppressive treatment. Although SLE-associated CVID is not common, it should be considered in any SLE patient with hypogammaglobulinemia (at least 2 standard deviations below the mean age in serum concentration of $\operatorname{IgG}$ and $\operatorname{IgA}$ ), absent or poor response to immunization (two-fold or less increase in antibody titer), and acute, chronic, or recurrent infections, specifically, pneumonia, bronchitis, sinusitis, conjunctivitis, and otitis media.

The clinical and bacterial spectrums of infections are similar in patients of CVID with or without SLE and include recurrent infections with encapsulated organisms, 
such as Streptococcus pneumoniae and Hemophilius influenzae. These patients also show an unusual susceptibility to Mycoplasma infections (89). Other unrelated causes of hypogammaglobulinemia in patients who have SLE are lymphoproliferative disorders, including myeloma, chronic lymphocytic leukemia, and lymphoma.

\section{IgA deficiency}

Mantovani et al. investigated the occurrence of $\operatorname{Ig} \mathrm{A}$ deficiency and reported a prevalence of $6.17 \%$ in 199 SLE patients, observing that it had no particular laboratory or clinical effects (90). Cassidy et al. calculated that the prevalence of $\operatorname{IgA}$ deficiency is $2.6 \%$ in adults $(n=152)$ and $5.2 \%$ in children $(n=77)$ with SLE. These patients have a similar clinical course compared to patients who have SLE without IgA deficiency (91).

\section{IgM deficiency}

Selective $\operatorname{IgM}$ deficiency has been described in patients who have SLE and was found more often in long-standing and less severe SLE cases (92). The most common clinical manifestations of selective $\operatorname{IgM}$ deficiency are infections with extracellular and intracellular bacteria, viruses, and fungi, that respond to conventional antibiotics/ antiviral/antifungal agents, without a need for prolonged antibiotic therapy, and occasional intravenous immunoglobulin (Ig) therapy (93).

\section{THERAPY-RELATED RISK FOR INFECTION IN SLE}

SLE treatment includes glucocorticoids, immunosuppressive agents such as cyclophosphamide, azathioprine, methotrexate, mycophenolate mofetil and cyclosporine, and biologics (Anti CD 20, Anti BLyS, Anti TNF). SLE patients treated with corticosteroids, immunosuppressive, and biologic agents have shown to be more susceptible to infections $(9,14)$.

\section{Glucocorticoids}

Glucocorticoids are the main drugs in the therapeutic armamentarium in SLE. They have a wide range of impacts on the immune system (94). Glucocorticoids have various anti-inflammatory and immunosuppressive effects triggered by several mechanisms, including interference with leucocyte, fibroblast and endothelial cell function. Glucocorticoids suppress cell-mediated immunity and also reduce the number of circulating monocytes and macrophages, thus increasing the risk for opportunistic infections (95, 96). They increase the risk of infection in SLE in a dose-dependent manner (95). The infection risk is considered greater, if prednisolone dose is $>15 \mathrm{mg}$. However, it is not clear whether there is a threshold below which glucocorticoids can be considered safe $(46,47)$.

\section{Cytotoxic drugs}

Cytotoxic drugs, including cyclophosphamide, mycophenolate mofetil (MMF), azathioprine and cyclosporine, are frequently used in combination with glucocorticoids for the treatment of severe SLE and can lead to a greater risk of infection.

\section{Cyclophosphamide}

Infection with a range of common and opportunistic pathogens is a frequent complication. Illei et al. reported higher frequency of infection in lupus nephritis patients treated with cyclophosphamide compared with patients treated with methylprednisolone alone (26\% vs 8\%) (97-100).

\section{Azathioprine}

The effect of azathioprine on the susceptibility to infection does not appear to be as strong as with cyclophosphamide, However, an increased frequency of infection in patients with SLE receiving azathioprine was reported in several studies (101-103).

\section{Mycophenolate mofetil}

Increased incidence of infection in patients with SLE receiving MMF was also noticed in several studies. However, the MAINTAIN and ALMS trials reported no significant difference in infection rates between MMF and azathioprine (102-104). Several controlled studies were performed comparing MMF and cyclophosphamide and dem- 
onstrated that the frequency of infection in patients treated with MMF (17-19\%) was similar or lower compared to patients treated with cyclophosphamide (105-107).

\section{Chloroquine/Hydroxychloroquine}

Hydroxychloroquine (HCQ) and chloroquine (CQ) have an anti-parasitic activity. They also have anti-bacterial, antifungal as well as anti-viral effects. These effects are exerted by $\mathrm{pH}$-dependent iron deprivation and increasing lysosomal $\mathrm{pH}$, leading to growth inhibition of intra-cellular organisms. Antibacterial effects are effective against $S$. aureus, tuberculosis, $S$. typhi and $E$. coli, while antifungal activity against Histoplasma, Cryptococcus and Aspergillus has also been reported $(108,109)$.

\section{Biological therapies}

Rituximab is an anti-CD20 monoclonal anti-body used in severe or refractory manifestations of SLE. The rate of infections in SLE patients treated with rituximab was reported as 19.5 per 100 patient/years. Infections were more frequent within the first six months of treatment (110-112).

The Spanish BIOGEAS study group recently described the rate and risk factors for severe infections in patients treated with biological agents. Biological therapies included were rituximab in $264(77 \%)$ patients, infliximab in $37(11 \%)$, etanercept in $21(6 \%)$, adalimumab in $19(5 \%)$, and other agents in $3(1 \%)$. Four deaths and forty-five severe infections were reported. The gross rate of severe infections was 90.9 events/1000 person-years (112.5 for rituximab, 76.9 for infliximab, 66.9 for adalimumab and 30.5 for etanercept respectively). The most frequent microorganisms seen were S.pneumonia followed by E.coli and S.aureus. The most common sites of severe infection were the lower respiratory tract $(39 \%)$, bacteremia/sepsis $(20 \%)$ and the urinary tract $(16 \%)$. Infections develop within the first six months $(63 \%)$ or after one year $(24 \%)$ after the administration of rituximab. The risk for severe infections was associated with the number of rituximab cycles received (113). Belimumab is a monoclonal antibody targeted against the soluble B lymphocyte stimulator (BLyS), which is a co-stimulator for B-cell function and survival. It has been recently approved in Europe and America for treating SLE patients who are clinically and serologically active, despite the standard therapy. At the recommended doses of $10 \mathrm{mg} / \mathrm{kg}$, the rate of serious infections is comparable with placebo (114-116).

Progressive multifocal leukoencephalopathy (PML) is a rare, potentially fatal, central nervous system (CNS) opportunistic infection of oligodendrocytes and astrocytes by John Cunningham virus (JC virus). JC virus reactivation occurs during periods of immunosuppression. Severe lymphopenia and a significant use of immunosuppressants, specifically rituximab and cyclophosphamide, were identified as potential risk factors. B cells may act as a potential viral reservoir or contribute to the immune response controlling JCV infection. Rituximab can achieve a robust peripheral blood B cell depletion (117-125).

\section{CONCLUSIONS}

Infections are a major and important cause of morbidity and mortality in patients with SLE due to the underlying immune dysregulation. SLE patients have a higher infection rate than the general population. Highdose glucocorticoids, high disease activity, organ dysfunction and use of biologics and immunosuppressants are the main risk factors for the development of an infection in SLE. Distinguishing between infections and flares of SLE is a significant challenge, as infections may mimic flares of SLE, leading to a predicament in diagnosis and appropriate management.

There is an urgent need for biomarkers for an appropriate differential diagnosis in this situation. However, in spite of increased understanding of SLE, many questions remain unanswered. Further research is needed to understand specific immune dysregulation underlying the increased susceptibility to specific infections, predictors of infection in SLE such as genetic markers, and biomarkers that discriminates between disease activity and active infec- 
tions. There is also a need to evaluate more appropriate measures to prevent infections and their complications in SLE patients.

\section{Contributions}

The authors contributed equally.

\section{Conflict of interest}

The authors declare no conflict of interest.

\section{REFERENCES}

1. Cervera R, Khamashta MA, Font J, et al. Morbidity and mortality in systemic lupus erythematosus during a 10-year period: a comparison of early and late manifestations in a cohort of 1,000 patients. Medicine (Baltimore). 2003; 82: 299-308.

2. Goldblatt F, Chambers S, Rahman A, Isenberg DA. Serious infections in British patients with systemic lupus erythematosus: hospitalisations and mortality. Lupus. 2009; 18: 682-9.

3. Petri M, Genovese M. Incidence of and risk factors for hospitalizations in systemic lupus erythematosus: a prospective study of the Hopkins Lupus Cohort. J Rheumatol. 1992; 19: $1559-65$.

4. Uramoto KM, Michet CJ Jr, Thumboo J, et al. Trends in the incidence and mortality of systemic lupus erythematosus, 1950-1992. Arthritis Rheum. 1999; 42: 46-50.

5. Rubin LA, Urowitz MB, Gladman DD. Mortality in systemic lupus erythematosus: the bimodal pattern revisited. Q J Med. 1985; 55: 87-98.

6. Rigante D, Mazzoni MB, Esposito S. The cryptic interplay between systemic lupus erythematosus and infections. Autoimmun Rev. 2014; 13: 96-102.

7. Berman S. Epidemiology of Acute Respiratory Infections in Children of Developing Countries. Clin Infect Dis. 1991; 13: S454-S462.

8. De Armas Rodriguez Y, Wissmann G, Muller AL, et al. Pneumocystis jirovecii pneumonia in developing countries. Parasite J Société Fr Parasitol. 2011; 18: 219-28.

9. Gladman DD, Hussain F, Ibañez D, Urowitz MB. The nature and outcome of infection in systemic lupus erythematosus. Lupus. 2002; 11: 234-9.

10. Al-Rayes H, Al-Swailem R, et al. Lupus Around the World Systemic lupus erythematosus and infections: a retrospective study in Saudis. Lupus. 2007; 16: 755-63.

11. Khalifa M, Kaabia N, Bahri F, et al. Infection in systemic lupus erythematosus. Médecine Mal Infect. 2007; 37: 792-5.

12. Bosch X, Guilabert A, Pallarés L, et al. Infections in systemic lupus erythematosus: a pro- spective and controlled study of 110 patients. Lupus. 2006; 15: 584-9.

13. Costa-Reis $P$, Nativ $S$, Isgro J, et al. Major infections in a cohort of 120 patients with juvenile-onset systemic lupus erythematosus. Clin Immunol Orlando Fla. 2013; 149: 442-9.

14. Noël V, Lortholary O, Casassus P, et al. Risk factors and prognostic influence of infection in a single cohort of 87 adults with systemic lupus erythematosus. Ann Rheum Dis. 2001; 60: 1141-4.

15. Kang TY, Lee HS, Kim TH, et al. Clinical and genetic risk factors of herpes zoster in patients with systemic lupus erythematosus. Rheumatol Int. 2005; 25: 97-102.

16. Borba EF, Ribeiro ACM, Martin P, et al. Incidence, risk factors, and outcome of Herpes zoster in systemic lupus erythematosus. J Clin Rheumatol Pract Rep Rheum Musculoskelet Dis. 2010; 16: 119-22.

17. Sekigawa I, Nawata M, Seta N, et al. Cytomegalovirus infection in patients with systemic lupus erythematosus. Clin Exp Rheumatol. 2002; 20: 559-64.

18. Rozenblyum EV, Allen UD, Silverman ED, Levy DM. Cytomegalovirus infection in childhood-onset systemic lupus erythematosus. Int J Clin Rheumatol. 2013; 8: 137-46.

19. Tam LS, Chan AYK, Chan PKS, et al. Increased prevalence of squamous intraepithelial lesions in systemic lupus erythematosus: association with human papillomavirus infection. Arthritis Rheum. 2004; 50: 3619-25.

20. Wiesik-Szewczyk E, Romanowska M, Mielnik $\mathrm{P}$, et al. Anti-influenza vaccination in systemic lupus erythematosus patients: an analysis of specific humoral response and vaccination safety. Clin Rheumatol. 2010; 29: 605-13.

21. Heijstek MW, Ott de Bruin LM, Bijl M, et al. EULAR recommendations for vaccination in paediatric patients with rheumatic diseases. Ann Rheum Dis. 2011; 70: 1704-12.

22. Stratton R, Slapak G, Mahungu T, Kinloch-de Loes S. Autoimmunity and HIV. Curr Opin Infect Dis. 2009; 22: 49-56.

23. Chu AD, Polesky AH, Bhatia G, Bush TM. Active and latent tuberculosis in patients with systemic lupus erythematosus living in the United States. J Clin Rheumatol Pract Rep Rheum Musculoskelet Dis. 2009; 15: 226-9.

24. Yun JE, Lee SW, Kim TH, et al. The incidence and clinical characteristics of Mycobacterium tuberculosis infection among systemic lupus erythematosus and rheumatoid arthritis patients in Korea. Clin Exp Rheumatol. 2002; 20: 127-32.

25. González León R, Garrido Rasco R, Chinchilla Palomares E, et al. Tuberculosis in a cohort of patients with systemic lupus erythematosus. Reumatol Clin. 2010; 6: 256-61.

26. Dodiuk-Gad R, Dyachenko P, Ziv M, et al. 
Nontuberculous mycobacterial infections of the skin: A retrospective study of 25 cases. J Am Acad Dermatol. 2007; 57: 413-20.

27. Hatzenbuehler LA, Starke JR. Common presentations of nontuberculous mycobacterial infections. Pediatr Infect Dis. J. 2014; 33: 89-91.

28. Fan YC, Li WG, Zheng MH, et al. Invasive fungal infection in patients with systemic lupus erythematosus: Experience from a single institute of Northern China. Gene. 2012; 506: 184-7.

29. Kim HJ, Park YJ, Kim WU, et al. Invasive fungal infections in patients with systemic lupus erythematosus: experience from affiliated hospitals of Catholic University of Korea. Lupus. 2009; 18: 661-6.

30. Chen HS, Tsai WP, Leu HS, et al. Invasive fungal infection in systemic lupus erythematosus: an analysis of 15 cases and a literature review. Rheumatol. 2007; 46: 539-44.

31. Kadoya A, Okada J, Iikuni Y, Kondo H. Risk factors for Pneumocystis carinii pneumonia in patients with polymyositis/dermatomyositis or systemic lupus erythematosus. J Rheumatol. 1996; 23: 1186-8.

32. Lertnawapan R, Totemchokchyakarn K, Nantiruj K, Janwityanujit S. Risk factors of Pneumocystis jeroveci pneumonia in patients with systemic lupus erythematosus. Rheumatol Int. 2009; 29: 491-6.

33. Zamir D, Amar M, Groisman G, Weiner P. Toxoplasma infection in systemic lupus erythematosus mimicking lupus cerebritis. Mayo Clin Proc. 1999; 74: 575-8.

34. Berkun Y, Zandman-Goddard G, Barzilai O, et al. Infectious antibodies in systemic lupus erythematosus patients. Lupus. 2009; 18: 112935.

35. Navarro-Zarza JE, Alvarez-Hernández E, Casasola-Vargas JC, et al. Prevalence of community-acquired and nosocomial infections in hospitalized patients with systemic lupus erythematosus. Lupus. 2010; 19: 43-8.

36. Ruiz-Irastorza G, Olivares N, Ruiz-Arruza I, et al. Predictors of major infections in systemic lupus erythematosus. Arthritis Res Ther. 2009; 11: R109.

37. Suh CH, Jeong YS, Park HC, et al. Risk factors for infection and role of C-reactive protein in Korean patients with systemic lupus erythematosus. Clin Exp Rheumatol. 2001; 19: 191-4.

38. Kim HA, Jeon JY, An JM, et al. C-reactive protein is a more sensitive and specific marker for diagnosing bacterial infections in systemic lupus erythematosus compared to S100A8/ A9 and procalcitonin. J Rheumatol. 2012; 39: 728-34.

39. Roy S, Tan KT. Pyrexia and normal C-reactive protein (CRP) in patients with systemic lupus erythematosus: always consider the possibility of infection in febrile patients with systemic lupus erythematosus regardless of CRP levels. Rheumatol Oxf Engl. 2001; 40: 349-50.

40. Williams RC Jr, Harmon ME, Burlingame R, $\mathrm{Du}$ Clos TW. Studies of serum C-reactive protein in systemic lupus erythematosus. J Rheumatol. 2005; 32: 454-61.

41. Hellmich B, Csernok E, de Haas M, et al. Low Fcgamma receptor III and high granulocyte colony-stimulating factor serum levels correlate with the risk of infection in neutropenia due to Felty's syndrome or systemic lupus erythematosus. Am J Med. 2002; 113: 134-9.

42. Egerer K, Feist E, Rohr U, et al. Increased serum soluble CD14, ICAM-1 and E-selectin correlate with disease activity and prognosis in systemic lupus erythematosus. Lupus. 2000; 9: 614-21.

43. Quintana G, Medina YF, Rojas C, et al. The use of procalcitonin determinations in evaluation of systemic lupus erythematosus. J Clin Rheumatol Pract Rep Rheum Musculoskelet Dis. 2008; 14: 138-42.

44. Bador KM, Intan S, Hussin S, Gafor AHA. Serum procalcitonin has negative predictive value for bacterial infection in active systemic lupus erythematosus. Lupus. 2012; 21: 1172-7.

45. Fei Y, Shi X, Gan F, et al. Death causes and pathogens analysis of systemic lupus erythematosus during the past 26 years. Clin Rheumatol. 2014; 33: 57-63.

46. Voss A, Laustrup H, Hjelmborg J, Junker P. Survival in systemic lupus erythematosus, 1995-2010. A prospective study in a Danish community. Lupus. 2013; 22: 1185-91.

47. Zhen J, Ling-Yun S, Yao-Hong Z, et al. Deathrelated factors of systemic lupus erythematosus patients associated with the course of disease in Chinese populations: multicenter and retrospective study of 1,958 inpatients. Rheumatol Int. 2013; 33: 1541-6.

48. Sharma A, Shamanna SB, Kumar S, et al. Causes of mortality among inpatients with systemic lupus erythematosus in a tertiary care hospital in North India over a 10-year period. Lupus. 2013; 22: 216-22.

49. Teh CL, Ling GR. Causes and predictors of mortality in hospitalized lupus patient in Sarawak General Hospital, Malaysia. Lupus. 2013; 22: 106-11.

50. Kang KY, Kwok SK, Ju JH, et al. The causes of death in Korean patients with systemic lupus erythematosus over 11 years. Lupus. 2011; 20: 989-97.

51. Souza DCC, Santo AH, Sato EI. Mortality profile related to systemic lupus erythematosus: a multiple cause-of-death analysis. J Rheumatol. 2012; 39: 496-503.

52. Abu-Shakra M. Safety of vaccination of patients with systemic lupus erythematosus. Lupus. 2009; 18: 1205-8. 
53. Van Assen S, Agmon-Levin N, Elkayam O, et al. EULAR recommendations for vaccination in adult patients with autoimmune inflammatory rheumatic diseases. Ann Rheum Dis. 2011; 70: 414-22.

54. Paton NI, Cheong IK, Kong NC, Segasothy M. Risk factors for infection in Malaysian patients with systemic lupus erythematosus. QJM Mon J Assoc Phys. 1996; 89: 531-8.

55. Duffy KN, Duffy CM, Gladman DD. Infection and disease activity in systemic lupus erythematosus: a review of hospitalized patients. J Rheumatol. 1991; 18: 1180-4.

56. Zonana-Nacach A, Camargo-Coronel A, Yañez $\mathrm{P}$, et al. Infections in outpatients with systemic lupus erythematosus: a prospective study. Lupus. 2001; 10: 505-10.

57. Jeong SJ, Choi H, Lee HS, et al. Incidence and risk factors of infection in a single cohort of 110 adults with systemic lupus erythematosus. Scand J Infect Dis. 2009; 41: 268-74.

58. Ng WL. Infections in patients with systemic lupus erythematosus. APLAR J Rheumatol. 2006; 9: 89-97.

59. Cuchacovich R, Gedalia A. Pathophysiology and clinical spectrum of infections in systemic lupus erythematosus. Rheum Dis Clin North Am. 2009; 35:75-93.

60. Wadee S, Tikly M, Hopley M. Causes and predictors of death in South Africans with systemic lupus erythematosus. Rheumatol Oxf Engl. 2007; 46: 1487-91.

61. Mayilyan KR. Complement genetics, deficiencies, and disease associations. Protein Cell. 2012; 3: 487-96.

62. Truedsson L, Bengtsson AA, Sturfelt G. Complement deficiencies and systemic lupus erythematosus. Autoimmun. 2007; 40: 560-6.

63. Ram S, Lewis LA, Rice PA. Infections of people with complement deficiencies and patients who have undergone splenectomy. Clin Microbiol Rev. 2010; 23: 740-80.

64. Mitchell SR, Nguyen PQ, Katz P. Increased risk of neisserial infections in systemic lupus erythematosus. Semin Arthritis Rheum. 1990; 20: 174-84.

65. Yoshida K, Yukiyama Y, Miyamoto T. Quantification of the complement receptor function on polymorphonuclear leukocytes: its significance in patients with systemic lupus erythematosus. J Rheumatol. 1987; 14: 490-6.

66. Mir A, Porteu F, Levy M, et al. C3b receptor (CR1) on phagocytic cells from SLE patients: analysis of the defect and familial study. Clin Exp Immunol. 1988; 73: 461-6.

67. Wilson JG, Ratnoff WD, Schur PH, Fearon DT. Decreased expression of the $\mathrm{C} 3 \mathrm{~b} / \mathrm{C} 4 \mathrm{~b}$ receptor (CR1) and the $\mathrm{C} 3 \mathrm{~d}$ receptor (CR2) on B lymphocytes and of CR1 on neutrophils of patients with systemic lupus erythematosus. Arthritis Rheum. 1986; 29: 739-47.
68. Yu CL, Tsai CY, Chiu CC, et al. Defective expression of neutrophil $\mathrm{C} 3 \mathrm{~b}$ receptors and impaired lymphocyte $\mathrm{Na}(+)-\mathrm{K}(+)$-ATPase activity in patients with systemic lupus erythematosus. Proc Natl Sci Counc Repub China B. 1991; 15: 178-85.

69. Boackle SA, Holers VM. Role of complement in the development of autoimmunity. Curr Dir Autoimmun. 2003; 6: 154-68.

70. Fossati-Jimack L, Ling GS, Cortini A, et al. Phagocytosis is the main CR3-mediated function affected by the lupus-associated variant of CD11b in human myeloid cells. PLoS One. 2013; 8: e57082.

71. Mok MY, Ip WKE, Lau CS, et al. Mannosebinding lectin and susceptibility to infection in Chinese patients with systemic lupus erythematosus. J Rheumatol. 2007; 34: 1270-6.

72. Forton AC, Petri MA, Goldman D, Sullivan KE. An osteopontin (SPP1) polymorphism is associated with systemic lupus erythematosus. Hum Mutat. 2002; 19: 459.

73. Pradhan V, Borse V, Ghosh K. PTPN22 gene polymorphisms in autoimmune diseases with special reference to systemic lupus erythematosus disease susceptibility. J Postgrad Med. 2010; 56: 239-42.

74. Lamsyah H, Rueda B, Baassi L, et al. Association of PTPN22 gene functional variants with development of pulmonary tuberculosis in Moroccan population. Tissue Antigens 2009; 74: 228-32.

75. Chen JY, Wang CM, Tsao KC, et al. Fcgamma receptor IIa, IIIa, and IIIb polymorphisms of systemic lupus erythematosus in Taiwan. Ann Rheum Dis. 2004; 63: 877-80.

76. Brambila-Tapia AJL, Dávalos-Rodríguez IP. Fcgamma receptor polymorphisms and systemic lupus erythematosus. Rev Investig Clínica Organo Hosp Enfermedades Nutr. 2009; 61: 66-72.

77. Janko C, Schorn C, Grossmayer GE, et al. Inflammatory clearance of apoptotic remnants in systemic lupus erythematosus (SLE). Autoimmun Rev. 2008; 8: 9-12.

78. Yu CL, Chang KL, Chiu CC, et al. Defective phagocytosis, decreased tumour necrosis factor-alpha production, and lymphocyte hyporesponsiveness predispose patients with systemic lupus erythematosus to infections. Scand J Rheumatol. 1989; 18: 97-105.

79. Durand V, Lamour A, Devauchelle V, et al. Fcgamma receptor reactivity in nonorgan-specific autoimmune diseases. Clin Rev Allergy Immunol. 2000; 18: 11-26.

80. Keeling DM, Isenberg DA. Haematological manifestations of systemic lupus erythematosus. Blood Rev. 1993; 7: 199-207.

81. Pradhan VD, Badakere SS, Bichile LS, Almeida AF. Anti-neutrophil cytoplasmic antibodies (ANCA) in systemic lupus erythematosus: 
prevalence, clinical associations and correlation with other autoantibodies. J Assoc Physicians India. 2004; 52: 533-7.

82. McIlwaine L, Parker A, Sandilands G, et al. Neutrophil-specific granule deficiency. $\mathrm{Br} \mathrm{J}$ Haematol. 2013; 160: 735.

83. Kocher M, Edberg JC, Fleit HB, Kimberly RP. Antineutrophil cytoplasmic antibodies preferentially engage Fc gammaRIIIb on human neutrophils. J Immunol. 1998; 161: 6909-14.

84. Alvarez I, Vazquez JJ, Fontan G, et al. Neutrophil chemotaxis and serum chemotactic activity in systemic lupus erythematosus. Scand J Rheumatol. 1978; 7: 69-74.

85. Stohl W, Hamilton AS, Deapen DM, et al. Impaired cytotoxic $\mathrm{T}$ lymphocyte activity in systemic lupus erythematosus following in vitro polyclonal $\mathrm{T}$ cell stimulation: a contributory role for non-T cells. Lupus. 1999; 8: 293-9.

86. Dörner T, Jacobi AM, Lee J, Lipsky PE. Abnormalities of $B$ cell subsets in patients with systemic lupus erythematosus. J Immunol Methods. 2011; 363: 187-97.

87. O'Neill SG, Isenberg DA. Immunizing patients with systemic lupus erythematosus: a review of effectiveness and safety. Lupus. 2006; 15: 778-83.

88. Lauter CB. Hypergammaglobulinemia, IgG2 Subclass Deficiency and Recurrent Infections in Adults. J Allergy Clin Immunol. 2006; 117: S106-S106.

89. Lindström F, Eriksson P, Denneberg T, et al. IgG2 deficiency in patients with hypergammaglobulinaemia. Lancet. 1992; 340: 979.

90. Fernández-Castro M, Mellor-Pita S, Citores $\mathrm{MJ}$, et al. Common variable immunodeficiency in systemic lupus erythematosus. Semin Arthritis Rheum. 2007; 36: 238-45.

91. Mantovani APF, Monclaro MP, Skare TL. Prevalence of IgA deficiency in adult systemic lupus erythematosus and the study of the association with its clinical and autoantibody profiles. Rev Bras Reumatol. 2010; 50: 273-82.

92. Cassidy JT, Kitson RK, Selby CL. Selective IgA deficiency in children and adults with systemic lupus erythematosus. Lupus 2007; 16: 647-50.

93. Saiki O, Saeki Y, Tanaka T, et al. Development of selective $\operatorname{IgM}$ deficiency in systemic lupus erythematosus patients with disease of long duration. Arthritis Rheum. 1987; 30: 1289-92.

94. Louis AG, Gupta S. Primary Selective IgM Deficiency: An Ignored Immunodeficiency. Clin Rev Allergy Immunol. 2014; 46: 104-11.

95. Riccardi C, Bruscoli S, Migliorati G. Molecular mechanisms of immunomodulatory activity of glucocorticoids. Pharmacol Res Off J Ital Pharmacol Soc. 2002; 45: 361-8.

96. Staples PJ, Gerding DN, Decker JL, Gordon RS Jr. Incidence of infection in systemic lupus erythematosus. Arthritis Rheum. 1974; 17: 1-10.
97. Badsha H, Kong KO, Lian TY, et al. Lowdose pulse methylprednisolone for systemic lupus erythematosus flares is efficacious and has a decreased risk of infectious complications. Lupus. 2002; 11: 508-13.

98. Illei GG, Austin HA, Crane M, et al. Combination therapy with pulse cyclophosphamide plus pulse methylprednisolone improves long-term renal outcome without adding toxicity in patients with lupus nephritis. Ann Intern Med. 2001; 135: 248-57.

99. Pryor BD, Bologna SG, Kahl LE.Risk factors for serious infection during treatment with cyclophosphamide and high-dose corticosteroids for systemic lupus erythematosus. Arthritis Rheum. 1996; 39: 1475-82.

100. Houssiau FA, Vasconcelos C, D’Cruz D, et al. Immunosuppressive therapy in lupus nephritis: the Euro-Lupus Nephritis Trial, a randomized trial of low-dose versus highdose intravenous cyclophosphamide. Arthritis Rheum. 2002; 46: 2121-31.

101. Guillevin L, Cordier JF, Lhote F, et al. A prospective, multicenter, randomized trial comparing steroids and pulse cyclophosphamide versus steroids and oral cyclophosphamide in the treatment of generalized Wegener's granulomatosis. Arthritis Rheum. 1997; 40: 2187-98.

102. Lee P, Urowitz MB, Bookman AA, Koehler BE, Smythe HA, Gordon DA, et al. Systemic lupus erythematosus. A review of 110 cases with reference to nephritis, the nervous system, infections, aseptic necrosis and prognosis. Q J Med. 1977; 46: 1-32.

103. Houssiau FA, D'Cruz D, Sangle S, et al. Azathioprine versus mycophenolate mofetil for long-term immunosuppression in lupus nephritis: results from the MAINTAIN Nephritis Trial. Ann Rheum Dis. 2010; 69: 2083-9.

104. Dooley MA, Jayne D, Ginzler EM, et al. Mycophenolate versus Azathioprine as Maintenance Therapy for Lupus Nephritis. N Engl J Med. 2011; 365: 1886-95.

105. Pisoni CN, Sanchez FJ, Karim Y, et al. Mycophenolate mofetil in systemic lupus erythematosus: efficacy and tolerability in 86 patients. J Rheumatol. 2005; 32: 1047-52.

106. Hu W, Liu Z, Chen H, et al. Mycophenolate mofetil vs cyclophosphamide therapy for patients with diffuse proliferative lupus nephritis. Chin Med J. 2002; 115: 705-9.

107. Kamanamool N, McEvoy M, Attia J, et al. Efficacy and adverse events of mycophenolate mofetil versus cyclophosphamide for induction therapy of lupus nephritis: systematic review and meta-analysis. Medicine (Baltimore). 2010; 89: 227-35.

108. Liu LL, Jiang Y, Wang LN, et al. Efficacy and safety of mycophenolate mofetil versus cyclophosphamide for induction therapy 
of lupus nephritis: a meta-analysis of randomized controlled trials. Drugs. 2012; 72: 1521-33.

109. Rolain JM, Colson P, Raoult D. Recycling of chloroquine and its hydroxyl analogue to face bacterial, fungal and viral infections in the 21 st century. Int $\mathbf{J}$ Antimicrob Agents. 2007; 30: 297-308.

110. Savarino A, Boelaert JR, Cassone A, et al. Effects of chloroquine on viral infections: an old drug against today's diseases? Lancet Infect Dis. 2003; 3: 722-7.

111. Witt M, Grunke M, Proft F, et al. Clinical outcomes and safety of rituximab treatment for patients with systemic lupus erythematosus (SLE) - results from a nationwide cohort in Germany (GRAID). Lupus. 2013; 22: 1142-9.

112. Bang SY, Lee CK, Kang YM, et al. Multicenter Retrospective Analysis of the Effectiveness and Safety of Rituximab in Korean Patients with Refractory Systemic Lupus Erythematosus. Autoimmune Dis. 2012: 565039.

113. Terrier B, Amoura Z, Ravaud P, et al. Safety and efficacy of rituximab in systemic lupus erythematosus: results from 136 patients from the French AutoImmunity and Rituximab registry. Arthritis Rheum. 2010; 62: 2458-66.

114. Díaz-Lagares C, Pérez-Alvarez R, GarcíaHernández FJ, et al. Rates of, and risk factors for, severe infections in patients with systemic autoimmune diseases receiving biological agents off-label. Arthritis Res Ther. 2011; 13: R112.

115. Furie R, Petri M, Zamani O, et al. A phase III, randomized, placebo-controlled study of belimumab, a monoclonal antibody that inhibits B lymphocyte stimulator, in patients with systemic lupus erythematosus. Arthritis Rheum. 2011; 63: 3918-30.

116. Navarra SV, Guzmán RM, Gallacher AE, et al. Efficacy and safety of belimumab in patients with active systemic lupus erythematosus: a randomised, placebo-controlled, phase 3 trial. Lancet. 2011; 377: 721-31.

117. Cassaniti I, Cavagna L, Calarota S, et al. Evaluation of EBV- and HCMV-Specific T Cell Responses in Systemic Lupus Erythematosus (SLE) Patients Using a Normalized Enzyme-Linked Immunospot (ELISPOT) Assay. J Immunol Res. 2019; 2019: 1-12.

118. Sève P, Ferry T, Koenig M, et al. Lupus-like presentation of parvovirus B19 infection. Semin Arthritis Rheum. 2005; 34: 642-8.

119. Castellino G, Govoni M, Trotta F. Comment on "Leishmania in SLE mimicking and exacerbation". Clin Exp Rheumatol. 2007; 25: 661.

120. Gómez J, Suárez A, López P, et al. Systemic Lupus Erythematosus in Asturias, Spain. Med. 2006; 85: 157-68.

121. Mehrotra R, Marsh D, Vonesh E, et al. Patient education and access of ESRD patients to renal replacement therapies beyond incenter hemodialysis. Kidney Int. 2005; 68: 378-90.

122. Zhou W, Yang C. The causes and clinical significance of fever in systemic lupus erythematosus: a retrospective study of 487 hospitalised patients. Lupus 2009; 18: 807-12.

123. Berger J, Malik V, Lacey S, et al. Progressive multifocal leukoencephalopathy in rituximab-treated rheumatic diseases: a rare event. J NeuroVirol. 2018; 24: 323-31.

124. Son C, Lee T, Bang J, et al. The relationship between anti-C-reactive protein and disease activity in patients with systemic lupus erythematosus. Korean J Intern Med. 2018; 33: 823-8.

125. Kapoor T, Mahadeshwar P, Hui-Yuen J, et al. Prevalence of progressive multifocal leukoencephalopathy (PML) in adults and children with systemic lupus erythematosus. Lupus Sci Med. 2020; 7: e000388. 